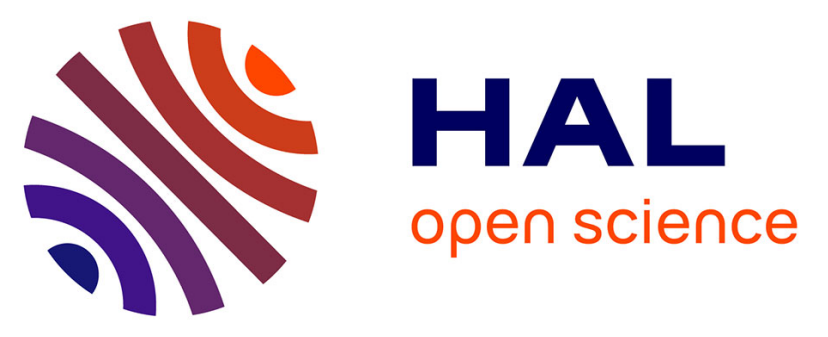

\title{
Retinoic acid maintains human skeletal muscle progenitor cells in an immature state
}

\author{
Marina El Hadad, Cécile Notarnicola, Brendan Evano, Nour El Khatib, \\ Marine Blaquière, Anne Bonnieu, Shahragim Tajbakhsh, Gerald Hugon, \\ Barbara Vernus, Jacques Mercier, et al.
}

\section{To cite this version:}

Marina El Hadad, Cécile Notarnicola, Brendan Evano, Nour El Khatib, Marine Blaquière, et al.. Retinoic acid maintains human skeletal muscle progenitor cells in an immature state. Cellular and Molecular Life Sciences, 2017, 74 (10), pp.1923-1936. 10.1007/s00018-016-2445-1 . hal-01607493

\section{HAL Id: hal-01607493 https://hal.science/hal-01607493}

Submitted on 4 Dec 2019

HAL is a multi-disciplinary open access archive for the deposit and dissemination of scientific research documents, whether they are published or not. The documents may come from teaching and research institutions in France or abroad, or from public or private research centers.
L'archive ouverte pluridisciplinaire HAL, est destinée au dépôt et à la diffusion de documents scientifiques de niveau recherche, publiés ou non, émanant des établissements d'enseignement et de recherche français ou étrangers, des laboratoires publics ou privés. 


\title{
Retinoic acid maintains human skeletal muscle progenitor cells in an immature state
}

\author{
Marina El Haddad ${ }^{1}$. Cécile Notarnicola ${ }^{1}$ - Brendan Evano ${ }^{2}$ - Nour El Khatib ${ }^{1}$. \\ Marine Blaquière $^{1} \cdot$ Anne Bonnieu $^{3} \cdot$ Shahragim Tajbakhsh $^{2}$ - Gérald Hugon ${ }^{1}$. \\ Barbara Vernus $^{3} \cdot$ Jacques Mercier $^{1,4}$ - Gilles Carnac ${ }^{1}$
}

Abstract Muscle satellite cells are resistant to cytotoxic
agents, and they express several genes that confer resis-
tance to stress, thus allowing efficient dystrophic muscle
regeneration after transplantation. However, once they are
activated, this capacity to resist to aggressive agents is
diminished resulting in massive death of transplanted cells.
Although cell immaturity represents a survival advantage,
the signalling pathways involved in the control of the
immature state remain to be explored. Here, we show that
incubation of human myoblasts with retinoic acid impairs
skeletal muscle differentiation through activation of the
retinoic-acid receptor family of nuclear receptor. Con-
versely, pharmacologic or genetic inactivation of
endogenous retinoic-acid receptors improved myoblast
differentiation. Retinoic acid inhibits the expression of
early and late muscle differentiation markers and enhances
the expression of myogenic specification genes, such as

Gilles Carnac

gilles.carnac@inserm.fr

Inserm U1046-UMR CNRS 9214 «Physiologie et Médecine Expérimentale du cœur et des muscles-PHYMEDEXP», CHU A. De Villeneuve, Université de Montpellier, Bâtiment Crastes de Paulet, 371 avenue du doyen Giraud, 34295 Montpellier Cedex 5, France

Stem Cells and Development, CNRS URA 2578, Department of Developmental and Stem Cell Biology, Pasteur Institute, 25 rue du Dr Roux, 75015 Paris, France

INRA, UMR866, Dynamique Musculaire et Métabolisme, Université Montpellier, 34060 Montpellier, France

Département de Physiologie Clinique, CHRU de Montpellier, 34295 Montpellier Cedex 5, France
$P A X 7$ and $P A X 3$. These results suggest that the retinoicacid-signalling pathway might maintain myoblasts in an undifferentiated/immature stage. To determine the relevance of these observations, we characterised the retinoicacid-signalling pathways in freshly isolated satellite cells in mice and in siMYOD immature human myoblasts. Our analysis reveals that the immature state of muscle progenitors is correlated with high expression of several genes of the retinoic-acid-signalling pathway both in mice and in human. Taken together, our data provide evidences for an important role of the retinoic-acid-signalling pathway in the regulation of the immature state of muscle progenitors.

Keywords Satellite cells $\cdot$ MyoD $\cdot$ RAR $\cdot$ Myoblasts · Differentiation

\section{Introduction}

Skeletal muscle has a remarkable ability to regenerate after repeated bouts of injury through the action of muscle stem (satellite) cells. In adult muscle, satellite cells are quiescent and represent about $2-7 \%$ of the nuclei associated with a muscle fibre. They are characterized by expression of the transcription factors PAX7 and MYF5 [1]. It has recently been demonstrated that only satellite cells are responsible for muscle regeneration: genetic ablation of satellite cells totally impairs skeletal muscle tissue repair [2,3]. After a trauma, satellite cells are activated, and they enter the cell cycle and begin to express the myogenic regulatory factor MYOD, in addition to PAX7 and MYF5. Satellite cell division can be symmetric, thus generating two equivalent daughter cells, or asymmetric, thus generating one selfrenewing daughter cell and one daughter cell committed to differentiation $[4,5]$. To ensure satellite cell self-renewal, a 
subpopulation of myogenic cells downregulates MYOD expression and enters the quiescent state [6]. The remaining myogenic cells exit the cell cycle, differentiate, and fuse to form myotubes that express MYOGENIN, MRF4, and myosin heavy chain (MHC) [7].

Transplanted myoblasts can fuse with endogenous muscle fibres to form hybrid myotubes [8], and this represents a viable approach for the treatment of inherited myopathies and diseases characterized by fibre necrosis and muscle weakness [9]. Myoblast transfer limitations, such as immune rejection or limited migration in the host tissue, are important, and in initial clinical trials, they were partially attributed to the poor survival rates of transplanted myoblasts [9-12]. Purified satellite cells implanted directly are more effective than satellite cells expanded in culture $[13,14]$. Therefore, it would be interesting to effectively control the transition from cell quiescence to cell activation ex vivo to optimize the production of cells suitable for transplantation. Recent reports have highlighted the unexpected role of NOTCH signalling in satellite cell quiescence $[15,16]$; however, the signalling pathways involved in the control of the quiescent state remain to be fully elucidated.

Among the different signalling pathways that regulate skeletal muscle development and growth, we focused on the retinoic-acid receptors' signalling pathway. Two classes of retinoic-acid receptors have been described: retinoicacid receptors (RARs) and retinoid $\mathrm{X}$ receptor (RXRs), each of which has three isoforms $\alpha, \beta$, and $\gamma$, encoded by separate genes. RARs mediate the effects of all-trans retinoic acid (RA), the active metabolite of vitamin A, and regulate many biological functions, such as proliferation and differentiation. An isomerization product of RA, 9-cis RA, also binds RARs, whereas RXRs only binds to 9-cis $\mathrm{RA}$ in vitro. Whether this compound is a natural bioactive retinoid remains controversial. RAR forms a heterodimer with RXR, binds to an RA response element (RARE) present in the promoter region of target genes, and upon ligand binding activates gene transcription [17]. In the absence of a ligand, the RAR-RXR heterodimer binds RARE associated with co-repressors and exerts a repressor activity on target gene expression [18, 19]. Retinoids (vitamin A and RA) have been shown to control skeletal muscle differentiation and the metabolism of mouse, zebrafish, and chicken skeletal muscle cells [20-24]. Recently, our group [25] and others [26, 27] have isolated human muscle progenitor cells characterized by high aldehyde dehydrogenase (ALDH; an enzyme involved in RA synthesis) activity and increased stress resistance and regenerative capacity. We also showed that RA, the final metabolite of ALDH, enhanced human myoblast viability by increasing the expression of the antioxidant enzyme glutathione peroxidase 3 (GPX3) [28]. Here, we investigated the role of RA in muscle progenitor cells. Using primary human myogenic cell cultures, we show that activation of the RA-signalling pathway prevents myoblast differentiation and transdifferentiation and up-regulated the expression of genes characteristics of more immature cells. We then characterised the RA-signalling pathways in freshly isolated satellite cells in mice and in siMYOD immature human myoblasts. Immature muscle cells overexpress several genes of the RA-signalling pathway both in mice and in human. Our findings indicate that RA signalling is more active in immature muscle cells and maintains skeletal muscle cells in an immature stage.

\section{Methods}

\section{Material}

All-trans RA was purchased from Sigma-Aldrich (St Quentin Fallavier, France). TTNPB (RAR agonist), LG 100268 (RXR agonist), and BMS493 (a RAR reverse agonist that blocks RAR activity) were purchased from Sigma-Aldrich (St Quentin Fallavier, France). RA and its agonists/antagonist were diluted in DMSO.

\section{Primary culture of human myoblasts}

Quadriceps muscle biopsies from healthy male adults (mean age $32.2 \pm 6.30$ years; $n=3$ ) were done at the Centre Hospitalier Universitaire Lapeyronie (Montpellier, France). All volunteers signed an informed written consent after description of the protocol. Myoblasts were purified from muscle biopsies as previously described [25] and were grown on collagen-coated dishes as previously described [28] in DMEM/F12 with $10 \%$ foetal bovine serum (FBS), $0.1 \%$ Ultroser $\mathrm{G}$, and $1 \mathrm{ng} / \mathrm{ml}$ of human basic FGF (growth medium). For cell differentiation, myoblasts were plated at $1.5 \times 10^{5}$ cells per $35 \mathrm{~mm}$ dishes in proliferating medium. Three days later, confluent myoblasts were cultured in DMEM with 2\% FBS for 3-5 days (differentiation medium).

\section{Mouse muscle satellite cell purification and culture}

Satellite cells were isolated by FACS from three 6-weekold Tg:Pax7-nGFP male mice [29]. Muscles (hindlimbs and forelimbs) were removed from bones, finely diced with 
small scissors, and put in $10 \mathrm{ml}$ of dissociation solution [DMEM (Life Technologies, France) supplemented with $0.08 \%$ collagenase D (Lifesciences, France), $0.1 \%$ trypsin (Life Technologies, France), and $10 \mu \mathrm{g} / \mathrm{ml}$ DNAse (Lifesciences, France)] at $37^{\circ} \mathrm{C}$ with gentle agitation for $30 \mathrm{~min}$. Supernatants were collected in $4 \mathrm{ml}$ foetal calf serum on ice. Then, $10 \mathrm{ml}$ dissociation solution was added and the digestion was repeated for five rounds. Dissociated muscles were sequentially filtered through 100,70 , and $40 \mu \mathrm{m}$ filters, centrifuged $\left(500 \mathrm{~g}, 4^{\circ} \mathrm{C}, 15 \mathrm{~min}\right)$ and washed once with cold DMEM supplemented with $2 \%$ FBS, centrifuged, and resuspended in DMEM with $2 \%$ FBS prior to cytometry. Satellite cells were isolated by FACS using a MoFlo Legacy apparatus (Beckman) and the Summit v4.3 software from DakoCytomation. Cells were displayed using the PE (Phycoerythrin, Red) and FITC channels on the FACS profile. Sorted, GFP-positive cells were collected in cold DMEM/2\% FBS supplemented with retinoic acid $(0,0.1$, or $1 \mu \mathrm{M})$, centrifuged, and resuspended in satellite cell growth medium [40\% DMEM, 40\% F12 (Thermo Fisher Scientific, France), 20\% FBS, 2\% Ultroser G (PallBiosepra, France), $1 \%$ penicillin/streptomycin], plated on Matrigel-coated dishes (Thermo Fisher scientific, France) at 5000 cells $/ \mathrm{cm}^{2}$, and grown at $37{ }^{\circ} \mathrm{C}, 5 \% \mathrm{CO}_{2}$, and $3 \%$ $\mathrm{O}_{2}$. Medium was changed every day with $10^{-7}, 10^{-6} \mathrm{M}$ RA. Control cells received vehicle alone $(0.1 \%$ DMSO, ctlr). EdU was used at $0.1 \mu \mathrm{M}$ for the first $24 \mathrm{~h}$ and then pulse for $2 \mathrm{~h}$ at $1 \mu \mathrm{M}$ before 48 and $72 \mathrm{~h}$ timepoints. EdU staining was chemically revealed with the Click-iT kit (Thermo Fisher Scientific).

\section{Differentiation assay}

Myoblasts were induced to differentiate in differentiation medium for 4 days in the presence of RA, TTNPB, LG, and BMS493 compounds for the first 2 days (refreshed after $24 \mathrm{~h}$ ) at the indicated concentrations. Control cells received vehicle alone (0.1\% DMSO, ctlr). Cells were fixed 2 days later (after 4 days of differentiation) for immunofluorescence or western blot analysis. Because differentiation is already optimal in our culture conditions, we changed the culture parameters to be able to measure the BMS493 effect on the size of myotubes by plating myoblasts at lower density $\left(8 \times 10^{4}\right.$ cells per $35 \mathrm{~mm}$ dishes in proliferating medium) to reduce the average myotube area. To test the reversibility of RA effect, when cell fusion was clearly identified in the control (day 2 of differentiation), differentiated cells treated with $10^{-7}$ M RA were washed with differentiation medium and then cultured in differentiation medium without RA (RA washed). Cells were fixed after 4 days of differentiation for immunofluorescence or western blot analysis.

\section{Immunofluorescence}

Human myoblasts were fixed in $2 \%$ paraformaldehyde (Electron Microscopy Sciences, Ayguesvives, France) in PBS and permeabilized with PBS $/ 0.25 \%$ Triton X-100. Cells were then incubated with mouse monoclonal antiTroponin T (1/200; Sigma-Aldrich) or rabbit polyclonal anti-myogenin (1/400; Santa Cruz Biotechology, Inc.) antibodies. Secondary antibodies were: Alexa 555-conjugated anti-mouse antibody (1/100; Thermo Fisher Scientific) and Alexa 488-conjugated anti-rabbit antibody (1/100; Thermo Fisher Scientific). Nuclei were revealed by DAPI staining. Mouse muscle cells were fixed in PFA $4 \% 5 \mathrm{~min}$ at room temperature, permeabilized (Triton $\mathrm{X}-100$ 0,5\%, $5 \mathrm{~min}$ ), blocked (Goat serum 10\%, $30 \mathrm{~min}$ ), and stained with mouse monoclonal anti-MyoD (1/200, dako) and Rabbit polyclonal anti-MyoG (1/200, Santa Cruz) antibodies overnight at $4{ }^{\circ} \mathrm{C}$ and goat anti-mouse Alexa 555 (Invitrogen) and goat anti-rabbit Alexa 633 (Thermo Fisher Scientific) secondary antibodies. EdU was detected with the Click-iT Plus EdU Alexa Fluor 488 Imaging Kit (Thermo Fisher Scientific). Images were taken with a Zeiss epifluorescence microscope and analysed with the Image $\mathbf{J}$ software.

\section{RT-qPCR}

Total RNA was isolated from cultured human muscle cells using the NucleoSpin RNA II Kit (Macherey-Nagel, Hoerdt, France). Satellite cells were resuspended in $350 \mu \mathrm{l}$ RLT Plus buffer (Qiagen, France) supplemented with $10 \% \beta$-mercaptoethanol, and RNA was extracted using the RNeasy Micro Kit (Qiagen, France) following the manufacturer's instructions. The RNA concentration of each sample was measured with an Eppendorf BioPhotometer. cDNA was prepared using the Verso cDNA Synthesis Kit (Thermo Scientific, Ilkirch, France). The expression of various genes was then analysed by quantitative polymerase chain reaction (qPCR) with a LightCycler apparatus (Roche Diagnostics, Meylan, France), as previously described [28], using the following primer sets: 


\begin{tabular}{|c|c|c|c|}
\hline & Gene & Forward primer & Reverse primer \\
\hline \multirow[t]{20}{*}{ Human } & PAX3 & GCCGCATCCTGAGAAGTAA & TGCCCTCCAAGTCACCC \\
\hline & PAX7 & CTGTGCCCTCAGGTTTAGT & TTCCCTTTGTCGCCCAG \\
\hline & $R P L P O$ & TCATCCAGCAGGTGTTCG & AGCAAGTGGGAAGGTGTAA \\
\hline & MYOD & ACAACGGACGACTTCTATGAC & TGCTCTTCGGGTTTCAGGA \\
\hline & MYF5 & CATGCCCGAATGTAACAGTC & CCCAGGTTGCTCTGAGG \\
\hline & MYOGENIN & ACCCCGCTTCTATGATGG & ACACCGACTTCCTCTTACACA \\
\hline & ACTAl & GACTTCTCAGGACGACGAATC & CATTTTCTTCCACAGGGCTT \\
\hline & Cyclin A & GCACTCTACACAGTCACGG & GTCTCTGGTGGGTTGAGGA \\
\hline & KI67 & CAAATCTCCGCAATCAGACC & CTGCTGCTTTAGGCGTG \\
\hline & $R A R \beta$ & GATGTAAGGGCTTTTTCCGC & TCATTCCTGACAGATTCTTTGGAC \\
\hline & GPX3 & CGGGGACAAGAGAAGTCG & CCCAGAATGACCAGACCG \\
\hline & $R B P 4$ & AGGAAATGATGACCACTGGAT & TGCCGCTGCCTTACAAT \\
\hline & STRA6 & TCCTGCCTACCATCCTCCT & AGACAGACCTCCACCCAAC \\
\hline & RDHIO & GTCTACCTGACGGCTGAAAG & TAGTGGTCCAGAAGTGTGC \\
\hline & $A D H I$ & ACTGATGGAGGTGTGGAT & TAGCAGCATAGGGTTTATTGAGAG \\
\hline & ALDHlal & ATGGATGCTTCCGAGAGG & GCCACATACACCAATAGGTTC \\
\hline & $A L P L$ & AAGCACTCCCACTTCATCTG & CACCACCACCATCTCGG \\
\hline & OSTERIX & GACTCAACAACTCTGGGCAA & GGGAAAAGGGAGGGTAATCA \\
\hline & $A P 2$ & ATCATCAGTGTGAATGGGGA & TCTCGTTTTCTCTTTATGGTGGTTG \\
\hline & $C E B P \alpha$ & GGCCAAGAAGTCGGTGGA & AGGCGGTCATTGTCACTG \\
\hline \multirow[t]{18}{*}{ Mouse } & $\operatorname{Pax3}$ & AGTCAGATGAAGGCTCCG & СTCCTCCCTGGTGTAAATGTC \\
\hline & $\operatorname{Pax} 7$ & GCTCAGAATCAAGTTCGGG & СССТCATCCAGACGGTT \\
\hline & Myod & GGCTCTCTCTGCTCCTTTGA & AGTAGGGAAGTGTGCGT \\
\hline & Myf5 & TCAGGAATGCCATCCGC & TGCTGTTCTTTCGGGACC \\
\hline & Cyclin A & CTTAGAAGACAAGCCAGTGAAC & AGCCAGTCCACAAGGAT \\
\hline & Rplpo & GGGCATCACCACGAAAATC & GCCGTTGTCAAACACCTG \\
\hline & Gpx3 & CCATTTGGCTTGGTCATTCTG & CTTTCTCCCCGTTCACATC \\
\hline & Rar $\alpha$ & AAAGAAGAAAGAGGCACCCAA & GTCCAGGGAGACTCGTT \\
\hline & $\operatorname{Rar} \beta$ & GGCTTTTTCCGCAGAAGTAT & TCATTCCTAACAGACTCTTTGGAC \\
\hline & $\operatorname{Rar\gamma }$ & CAAGATTGTGGAGTTTGCGAA & CCCATCCGAGAATGTCATAGT \\
\hline & Rxr $\alpha$ & ATGAGAACGAGGTGGAGT & TGCTGCTTGACAGATGTTGGTAA \\
\hline & $\operatorname{Rxr} \beta$ & GAAGAGTGACCAAGGCG & GTAGGGAGGAGAAGTGCG \\
\hline & $R x r y$ & ATCTACACCTGTCGGGATAAC & TGGCTACTACTGGCACATTC \\
\hline & Rbp4 & TGTGGACGAGAAGGGTCA & TCGCTGGAGAAAGGAGGCTA \\
\hline & Stra6 & CAATCTTCAAGCACTACACCGA & ATGCAGTAAAGGCACAAACAC \\
\hline & $\operatorname{Rdh} 10$ & CTGGGACTGTTCAGCACT & TGCCCGTGTCTACAAGGTAAG \\
\hline & Adhl & GCATTGTTGAGAGCGTTGG & GTCCCCCGAGGCATTAG \\
\hline & Aldhlal & GTGAAAAGGAGTGTTGAGCGA & TTTGTTCCCCCAGCGTC \\
\hline
\end{tabular}

\section{Western blotting}

Cells were lysed in hypotonic buffer (5\% anti-protease, $50 \mathrm{mM}$ Tris $\mathrm{pH} 7,50 \mathrm{mM} \mathrm{NaCl}, 0.1 \% \mathrm{NP} 40$ ), and protein concentrations were determined using the BioRad Protein Assay. $25 \mu \mathrm{g}$ of total proteins diluted in Laemmli buffer (50 mM Tris-HCl, pH 6.8, 20\% SDS, $10 \%$ glycerol, $100 \mathrm{mM}$ Dithiothreitol, and Bromophenol Blue) were separated by SDS-PAGE gel electrophoresis and transferred to nitrocellulose membranes, blocked at room temperature with Odyssey blocking buffer for $45 \mathrm{~min}$, and probed at $4{ }^{\circ} \mathrm{C}$ overnight with the following primary antibodies: mouse monoclonal anti- $\alpha$-tubulin (Sigma-Aldrich) diluted 1/10,000; mouse monoclonal anti-MHC slow (Sigma-Aldrich) diluted 1/2000; mouse monoclonal anti-Troponin $\mathrm{T}$ (Sigma-Aldrich) diluted $1 / 5000$; monoclonal anti- $\alpha$-actinin (Sigma-Aldrich) diluted 1/5000; and rabbit polyclonal anti-MyoD diluted 
Fig. 1 Retinoic acid inhibits human myoblast differentiation. Human myoblasts were induced to differentiate in differentiation medium for 4 days in the presence of increasing concentrations of RA or not (ctrl) for the first $48 \mathrm{~h}$ (refreshed after 24 h). a Representative images (six fields for each condition) showing myogenin (red) and Troponin T (green) expression. DNA was stained with DAPI (blue).

b Quantification of the percentage of myogeninpositive nuclei relative to all cell nuclei and $\mathbf{c}$ quantification of the average area of myotubes (in $\mu \mathrm{m}^{2}$ ) in the cultures, as shown in a. $p \leq 0.05(*)$ and $p \leq 0.01$ (**). Scale bars $^{*}$ $10 \mu \mathrm{M}$ a
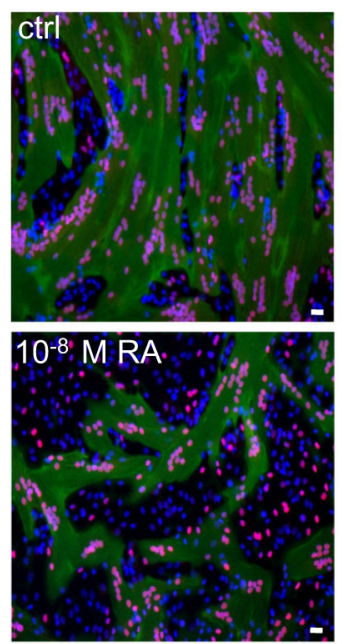

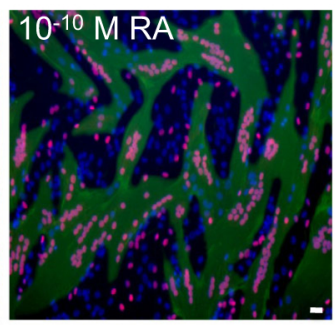

b

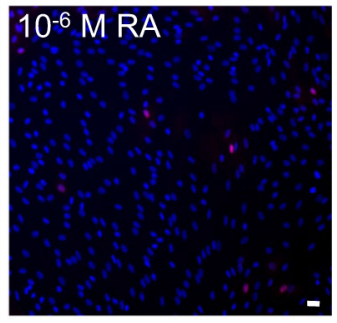

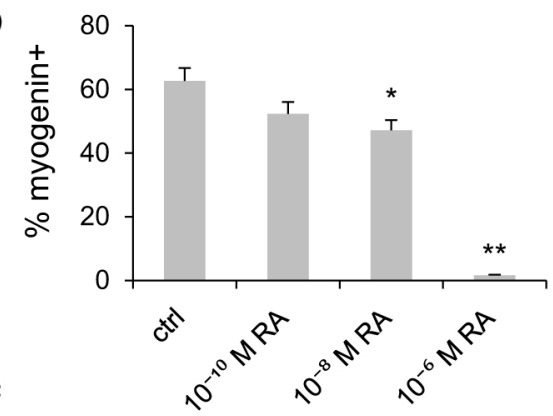

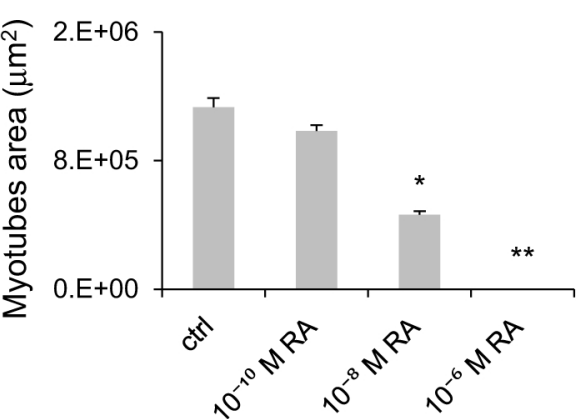

1/1000 (C20, SantaCruz). Membranes were washed in PBS/0.1\% Tween and incubated with horseradish peroxidase-conjugated anti-mouse secondary antibodies (GE Healthcare, Velizy-Villacoublay, France). Proteins bands were quantified with the Odyssey software and data normalized to $\boldsymbol{\alpha}$-tubulin expression.

\section{Transient siRNA transfections}

MYOD (siMYOD), RAR $\alpha$ (siRAR $\alpha), R A R \beta$ (siRAR $\beta$ ), $R A R \gamma$ (siRAR $\gamma$ ), and negative control (siCTRL) Silencer Select pre-designed siRNAs were purchased from Life Technologies (France). Human myoblasts were transfected with siMYOD and siCTRL as previously described [28] once (time 0 ) and harvested 72-96 h after transfection. siRAR $\alpha, \operatorname{siRAR} \beta, \operatorname{siRAR} \gamma$, and siCTRL were transfected once at proliferative stage, and a second time on the day the cells is induced to differentiate. Cells were analysed after 3-4 days of differentiation.

\section{Statistical analysis}

Each experiment was done at least in triplicate and performed in three independent human myoblast clones. Error bars represent the standard deviation of the mean. Statistical significance was determined using the Mann-Whitney test; $p<0.05(*), p<0.01(* *)$, and $p<0.001(* * *)$ were considered significant.

\section{Results}

\section{Retinoic acid inhibits differentiation of human myoblasts}

To determine whether RA had an impact on human myoblast differentiation, confluent human primary myoblasts were switched to differentiation medium for 4 days with different concentrations of RA (from $10^{-10}$ to $10^{-6} \mathrm{M}$ ). Cell differentiation was then assessed by immunofluorescence analysis with antibodies against two muscle differentiation markers: Troponin $\mathrm{T}$, a protein of the cytoplasmic cytoskeleton (green), and myogenin, a nuclear transcription factor (red) (Fig. 1a). Quantification of the immunofluorescence data showed that the percentage of myogenin-positive nuclei relative to all nuclei (Fig. 1b) and the myotube average area (Fig. 1c) decreased progressively in differentiating myoblasts in function of the RA concentration compared to controls. Myoblast differentiation was fully inhibited by $10^{-6} \mathrm{M}$ RA. To determine whether RA-mediated inhibition of differentiation was reversible, differentiating myoblasts treated with $10^{-7} \mathrm{M}$ RA were either washed or maintained in the same differentiation medium for 4 days (Fig. 2a). At the end of this period, the percentage of myogenin-positive nuclei (Fig. 2b) and the average myotube area (Fig. 2c) were significantly decreased in RA-treated cells compared to controls. However, in cells in which RA was washed, muscle differentiation was restored to levels (myogeninpositive nuclei and myotube area) comparable to those of 
control cultures. These immunofluorescence data were confirmed by western blotting (Fig. 2d) using antibodies against the differentiation markers MYHC slow and Troponin T. As expected, MYHC slow and Troponin T protein levels were strongly reduced after RA addition, but they were restored to control values in cells in which RA was washed off. Taken together, these results confirm that RA inhibits skeletal muscle differentiation in a reversible manner.

\section{Retinoic-acid inhibitory effect on myoblast differentiation is mediated by the RAR subfamily}

All-trans RA acts through binding to the RAR and RXR receptors. To determine the role of these two receptor classes in RA inhibitory effect on myoblast differentiation, human myoblasts were incubated with $10^{-6} \mathrm{M}$ RA, TTNPB (RAR agonist), or LG 100268 (RXR agonist) and induced to differentiate as described above. Myoblast differentiation was then monitored by immunofluorescence analysis with antibodies against the two muscle differentiation markers Troponin $\mathrm{T}$ (green) and myogenin (red)
Fig. 3 RAR activation prevents human myoblast differentiation. Human myoblasts were induced to differentiate in differentiation medium for 4 days in the presence of $10^{-6} \mathrm{M}$ RA, $10^{-6} \mathrm{M}$ TTNPB (RAR agonist), $10^{-6} \mathrm{M}$ LG100268 (LG; RXR agonist), $10^{-7} \mathrm{M}$ BMS493 (RAR agonist inverse), or not (ctrl) for the first $48 \mathrm{~h}$ (refreshed after $24 \mathrm{~h}$ ). Because differentiation is already optimal in our culture conditions, we changed the culture parameters to be able to measure the BMS493 effect on the size of myotubes by plating myoblasts at lower density to reduce the average myotube area. a Images ( condition) showing immunofluorescence analysis of myogenin (red) and Troponin T (green) expression in RA, TTNPB, and LG-treated myoblasts. DNA was stained with DAPI (blue). b Quantification of the percentage of myogenin-positive nuclei relative to all nuclei and c quantification of the average area of myotubes (in $\mu \mathrm{m}^{2}$ ) in control cultures and in cells treated with RA, TTNPB, or LG, as shown in a.d Images ( $s i x$ fields for each condition) showing immunofluorescence analysis of Troponin T (green) expression in ctrl and BMS 493 treated myoblasts. DNA was stained with DAPI (blue). e, fQuantification of the immunofluorescence data for the cultures shown in $\mathbf{d}$ : e myotube fusion index (number of nuclei in myotubes relative to the total number of nuclei) and $\mathbf{f}$ myotube average area (in $\mu \mathrm{m}^{2}$ ), calculated using the Image J software. $\mathbf{g}-\mathbf{j}$ Myoblast were transfected with siCTRL, siRAR $\alpha, \beta$, or $\gamma$ and induced to differentiate for 3-4 days. $\operatorname{RAR} \alpha, \operatorname{RAR} \beta$, or $\operatorname{RAR} \gamma$ mRNA levels (h). Troponin $\mathrm{T}$ immunofluorescence pictures (g; Troponin T green, DAPI blue) were quantified to determine the fusion index (i) and the myotube average area (j). $p \leq 0.05(*) ; p \leq 0.01$ (**). Scale bars $10 \mu \mathrm{M}$
Fig. 2 Retinoic acid exerts a reversible inhibition on human myoblast differentiation.

Human myoblasts were treated or not (ctrl) with $10^{-7} \mathrm{M}$ RA for 2 days. RA was then washed off (or not), and cells were allowed to differentiate for 4 days.

a Representative images (six fields for each condition) showing immunofluorescence analysis of myogenin (red) and Troponin $\mathrm{T}$ (green) expression. DNA was stained with DAPI (blue). b Quantification of the percentage of myogeninpositive nuclei relative to all cell nuclei and c quantification of the average area of myotubes (in $\mu \mathrm{m}^{2}$ ) in the cultures shown in a. d Western blotting was performed using antibodies against the muscle differentiation markers myosin heavy chain slow (MYHCs) and Troponin T. The expression of alpha tubulin ( $\alpha$-tubulin) was used as loading control.

$p \leq 0.05(*)$. Scale bars $10 \mu \mathrm{M}$

\section{a}
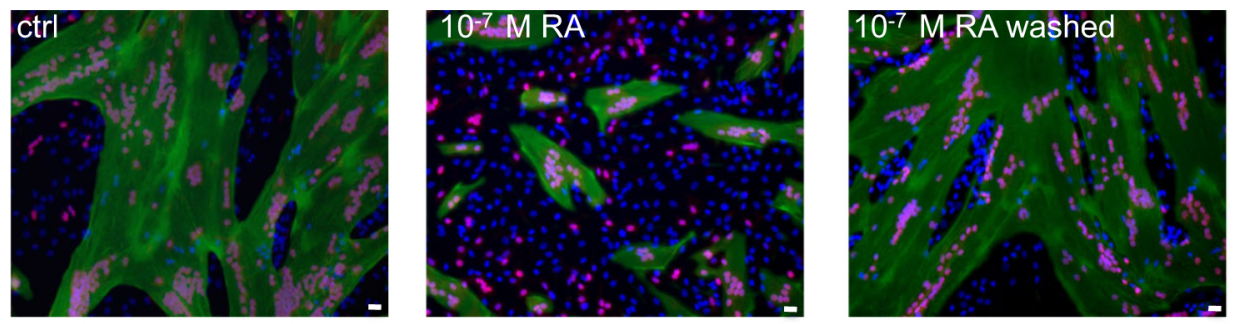

b

C
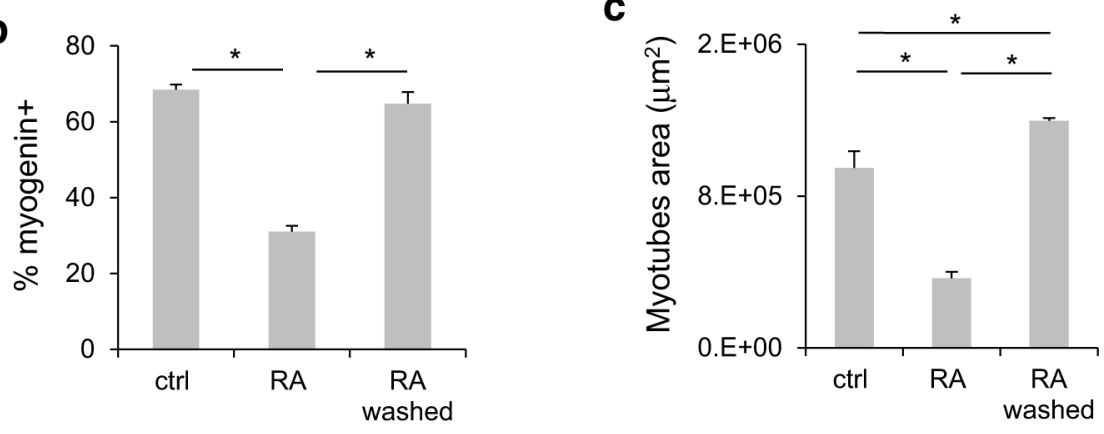

d ctrl RA RA

washed

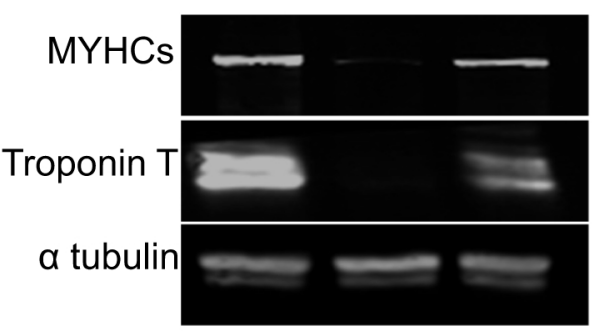



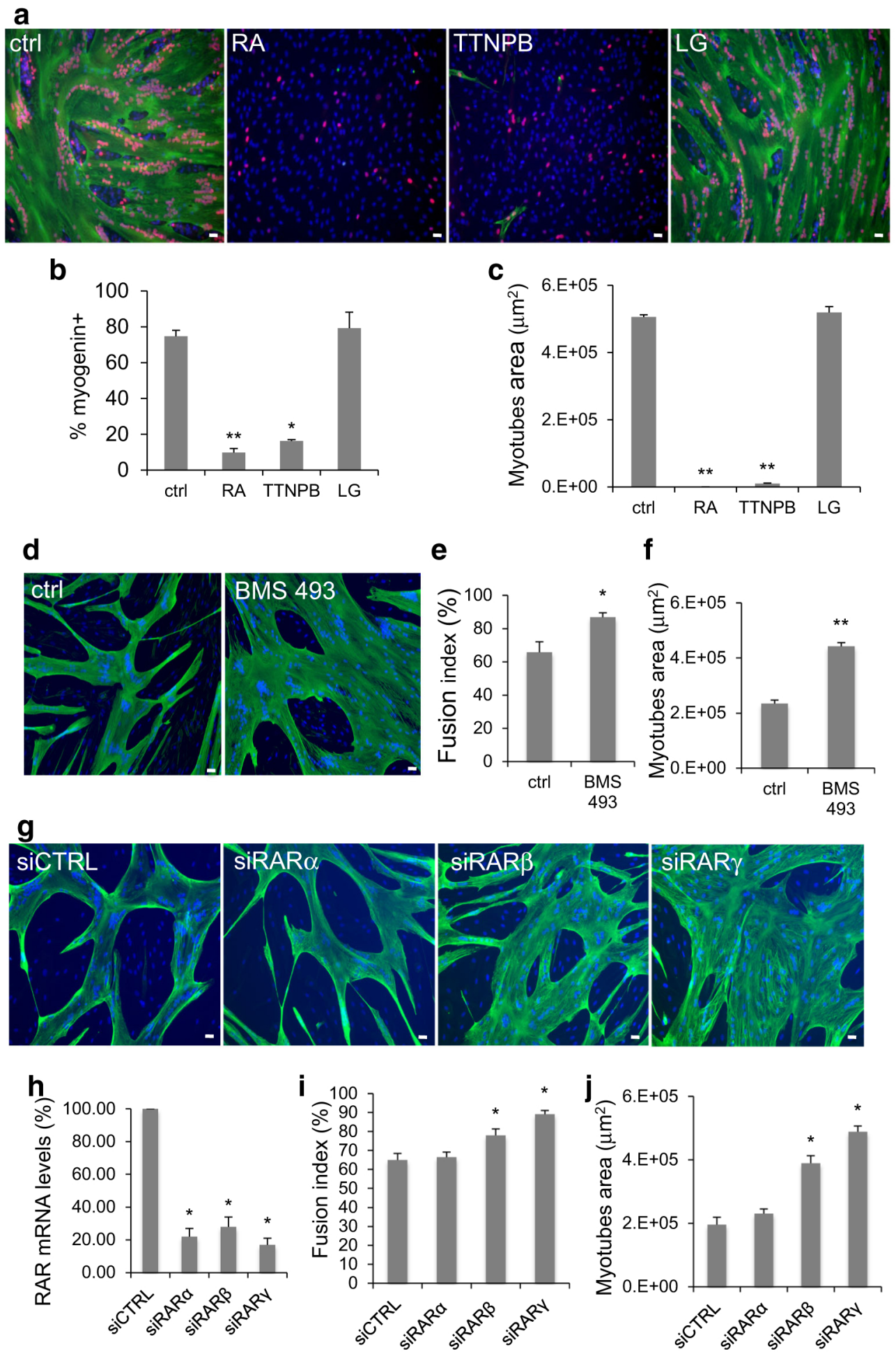
(Fig. 3a). Data quantification showed that the percentage of myogenin-positive nuclei relative to all nuclei (Fig. 3b) and the myotube surface area (Fig. 3c) were significantly and similarly reduced in cultures treated with RA or TTNPB, compared to controls and cells incubated with LG100268. These results indicate that RA inhibits myoblast differentiation through RAR activation. To better understand the role of endogenous RAR on myoblast differentiation, first, we treated differentiating myoblasts with $10^{-7} \mathrm{M}$ BMS493, a pan-retinoic-acid receptor (pan-RAR) inverse agonist that enhances nuclear corepressor (NCoR) interaction with RARs and blocks their activities [30]. Quantification of the immunofluorescence data (Fig. 3d) showed that the percentage of cell fusion (Fig. 3e) and the average myotube area increased in BMS493 treated myoblasts (Fig. 3f). Interestingly, we observed that BMS493 treatment increased the number of myogenin but not MYOD-positive cells (Fig. s1; Supplementary materials), suggesting that enhanced repression of RAR receptor activity by BMS493 improved myogenesis by increasing the number of myoblasts recruited into the differentiation process.

Then siRNA-mediated knock-down was used to study more specifically the effect of $\operatorname{RAR} \alpha, \operatorname{RAR} \beta$, or $\operatorname{RAR} \gamma$ depletion on myoblast differentiation. $\operatorname{RAR} \alpha, \operatorname{RAR} \beta$, or RAR $\gamma$ silencing was confirmed at the mRNA levels in primary myoblasts, respectively, transfected with $\operatorname{siRAR} \alpha$, siRAR $\beta$, or siRAR $\gamma$ compared with cells transfected with siCTRL (negative control siRNA) (Fig. 3h). We showed that $\operatorname{siRAR} \beta$ or $\operatorname{siRAR} \gamma$ but not siRAR $\alpha$ improves myoblast differentiation by enhancing the percentage of cell fusion (Fig. 3g, i) and the myotube surface area (Fig. 3g, j). Altogether, these results indicate that endogenous RARs negatively regulate human myoblast differentiation.

\section{Retinoic acid inhibits expression of genes involved in myogenic differentiation but not specification}

To determine the molecular basis of RA inhibition of myoblast differentiation, we followed by RT-qPCR the expression of several genes involved in myoblast specification (PAX7 and PAX3; upstream genes) identity (MYOD and MYF5; downstream genes) and differentiation (myogenin and ACTA1) in primary cultures of human myoblasts incubated with $10^{-7} \mathrm{M}$ RA (Fig. 4). Compared to controls, $P A X 3$ and $P A X 7$ expression remained stable during the first $8 \mathrm{~h}$ and increased significantly after $24 \mathrm{~h}$ of RA treatment. Conversely, MYOD and MYF5 were significantly inhibited after $4 \mathrm{~h}$ of incubation with RA and this inhibition was maintained over time. Expression of myogenin and ACTA1 was significantly inhibited only after $48 \mathrm{~h}$ of treatment. These observations indicate that RA inhibits the expression of commitment and differentiation genes, whereas upstream genes were up-regulated.

\section{Mice satellite cells express genes involved in retinoic-acid signalling}

Our results suggest that RA maintains human myoblast in an immature/undifferentiated state. To determine the relevance of these observations, we characterised the RAsignalling pathways in immature muscle progenitor cells (Fig. 5). Satellite cells are the most immature cells of the

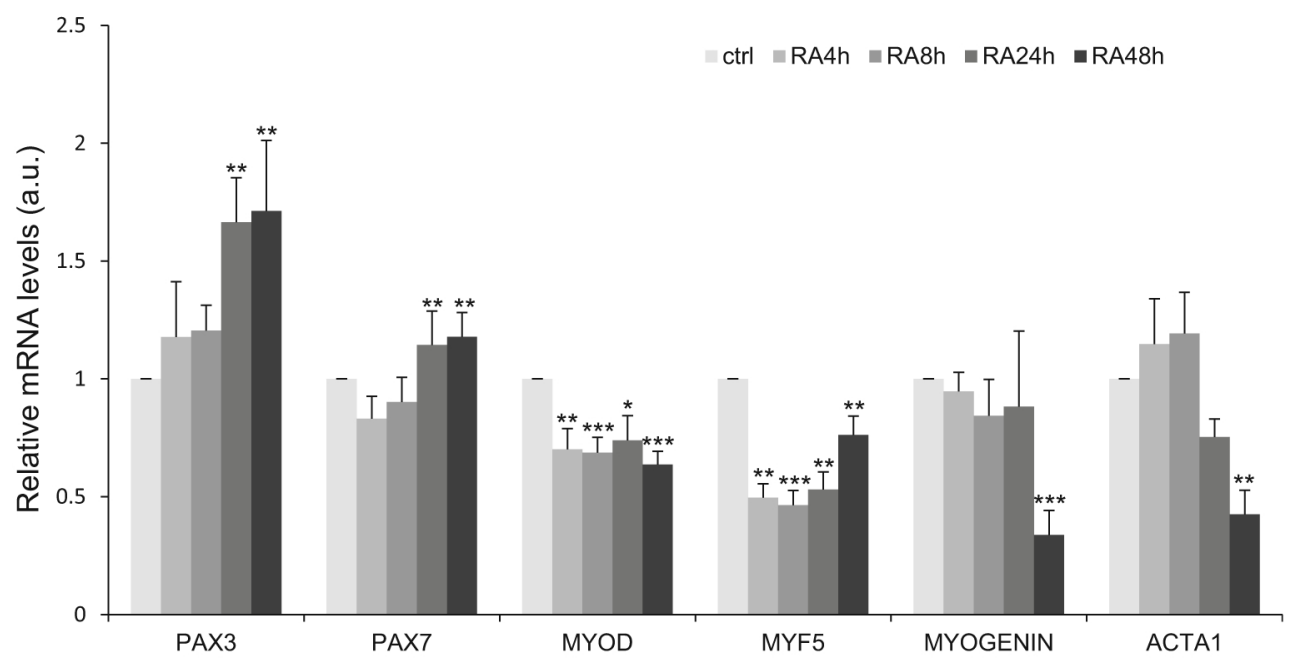

Fig. 4 Retinoic acid inhibits the expression of members of the $M Y O D$ gene family, but preserves the expression of the determination genes PAX7 and PAX3. RT-qPCR analysis of the expression of myogenic determination and differentiation genes in human myoblasts incubated or not (ctrl) with $10^{-7} \mathrm{M}$ RA for $48 \mathrm{~h}$. $p<0.05(*), p<0.01(* *)$, and $p<0.001(* * *)$. Data are shown as mRNA levels relative to the expression in Ctrl/non-treated cells at each timepoint, which was set at 1 
Fig. 5 RA-signalling pathway is activated in quiescent mouse satellite cells. a Graph showing GFP-positive satellite cells isolated by FACS from adult Tg: Pax7-nGFP mice $(n=3)$. b RT-qPCR analysis of the expression of myogenic determination, differentiation and proliferation genes, some RA-target genes, RA receptors, and genes encoding proteins involved in RA biogenesis in quiescent and activated mouse satellite cells. c Percentage of EdU, MyoD, and myogeninpositive nuclei relative to all cell nuclei in activated mouse satellite cells treated (RA) or not (ctrl) with $10^{-7} \mathrm{M}$ RA or $10^{-6} \mathrm{M}$ RA for indicated days. $p<0.05$ $(*), p<0.01(* *)$, and $p<0.001(* * *)$ a

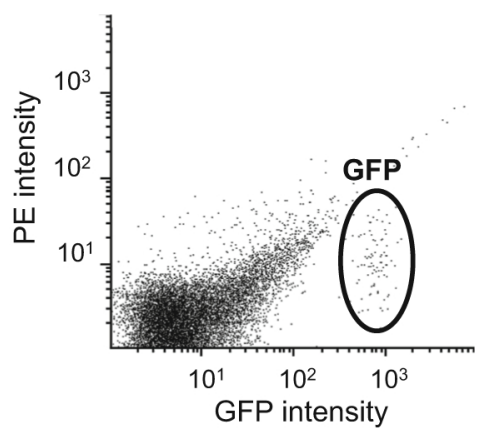

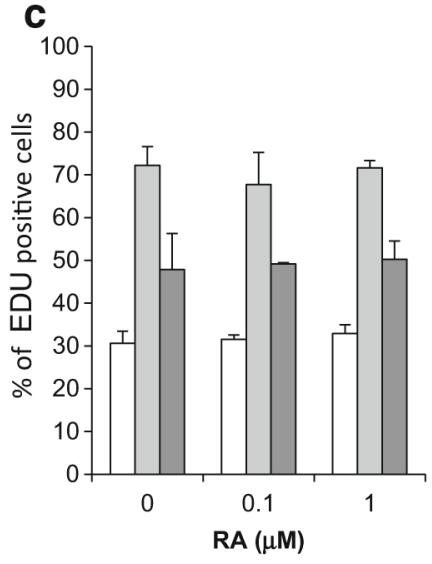
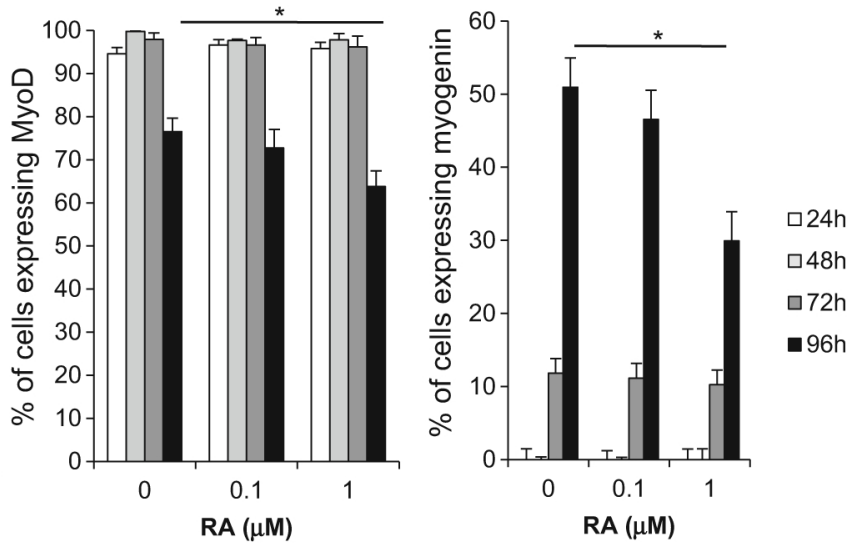

skeletal muscle lineage in adults. To investigate the expression of genes involved in RA signalling in satellite cells, we isolated quiescent mouse satellite cells by FACS from Tg:Pax7-nGFP male mice (Fig. 5a). To compare quiescent and activated satellite cells, a fraction of the purified, quiescent GFP-positive satellite cells was cultured in growth medium for 2 days. We analysed by RT-qPCR analysis expression of several genes involved in myogenesis (Pax3, Pax7, Myod, and Myf5) and cell proliferation (Cyclin A). We also determined the expression of RA-target genes (Gpx3 and $\operatorname{Rar} \beta$ ) [28, 31], genes encoding receptors of the RAR and RXR subfamily (Rara, $\operatorname{Rar} \beta$, $\operatorname{Rar} \gamma, \operatorname{Rxr} \alpha, \operatorname{Rxr} \beta$, and $R x r \gamma)$, and some genes encoding proteins involved in RA biogenesis: retinol binding protein 4 (Rbp4) which transports retinol in the blood; stimulated by retinoic acid 6 (Stra6), a membrane receptor for RBP4 that facilitates retinol uptake inside the cell; alcohol dehydrogenase 1 (Adhl); and retinol dehydrogenase 10 (Rdh10), which convert retinol to retinaldehyde that is then irreversibly oxidized to RA by retinaldehyde dehydrogenase the main isoform of which in human myoblasts is ALDH1a1 [25, 32] (Fig. 5b). As expected, Pax3 and Pax7 levels were significantly higher in quiescent compared to activated satellite cells. Cyclin A expression was higher in proliferating/activated satellite cells. Satellite cell activation was associated with higher Myod expression but no 
significant change in Myf5 mRNA levels. Rar $\beta$ and Gpx3 were strongly increased in quiescent cells. Among the RA receptors, only $\operatorname{Rar} \beta, \operatorname{Rar} \gamma$, and $\operatorname{Rxr} \beta$ were significantly more expressed in quiescent than in activated satellite cells. All genes involved in RA biosynthesis were overexpressed in quiescent satellite cells. These findings indicate that RA signalling is more active in quiescent than in activated satellite cells. To determine the impact of RA on satellite cell activation, mouse satellite cells isolated by FACS from Tg:Pax7-nGFP male mice were incubated with $10^{-7} \mathrm{M}$ RA, $10^{-6} \mathrm{M}$ RA, or $0.1 \%$ DMSO (control) for 4 days, and then, proliferation was quantified by EdU staining and the number of MYOD and myogenin-positive cells was assessed by immunofluorescence (Fig. $5 \mathrm{c}$ ). The number of cycling, MYOD, and myogenin-positive cells was not altered by RA treatments during the first 3 days of culture
Fig. 6 MYOD silencing blocks human myoblast differentiation and activates the retinoic-acidsignalling pathway.

a Representative images (six fields from each condition) showing immunofluorescence analysis of the expression of myogenin (red) and Troponin $\mathrm{T}$ (green) in human myoblasts transfected with siCTRL (control) or siMYOD. DNA was stained with DAPI (blue).

b Quantification of the percentage of myogeninpositive nuclei relative to all nuclei (left panel) and of the average area of myotubes in the cultures shown in a. c Western blot analysis of the expression of MyoD and the muscle differentiation markers MYHC slow (MYHCs), Troponin T, and alpha-actinin ( $\alpha$-actinin) in human myoblasts transfected with siCTRL or siMYOD. Alpha tubulin ( $\alpha$-tubulin) was used as loading control. d RTqPCR analysis of the expression of myogenic determination genes in human myoblasts transfected with siMYOD relative to myoblasts transfected with sictrl (set to 1). e RT-qPCR evaluation of the expression of the RA-target genes $R A R \beta$ and $G P X 3$ in human myoblasts transfected with siCTRL or siMYOD incubated (+RA) or not (-RA, 0.1\% DMSO) with RA. f RT-qPCR analysis of the expression of genes involved in the RA-signalling pathway in myoblasts transfected with siMYOD relative to control myoblasts (siCTRL). $p \leq 0.05$ $(*), p<0.01(* *)$. Scale bars $10 \mu \mathrm{M}$
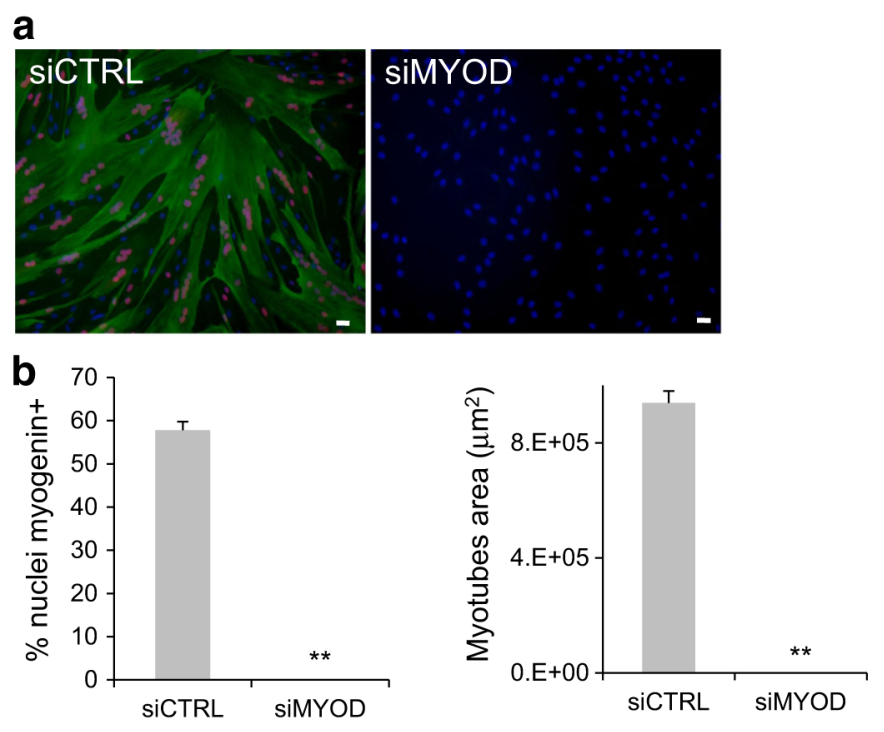

C

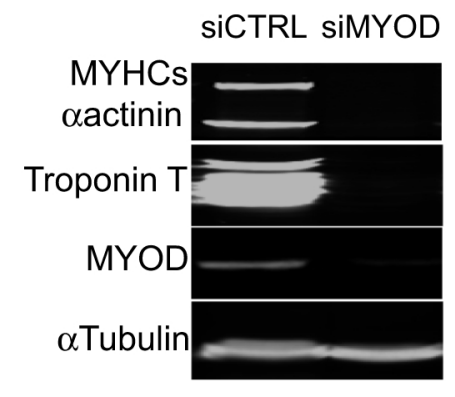

d
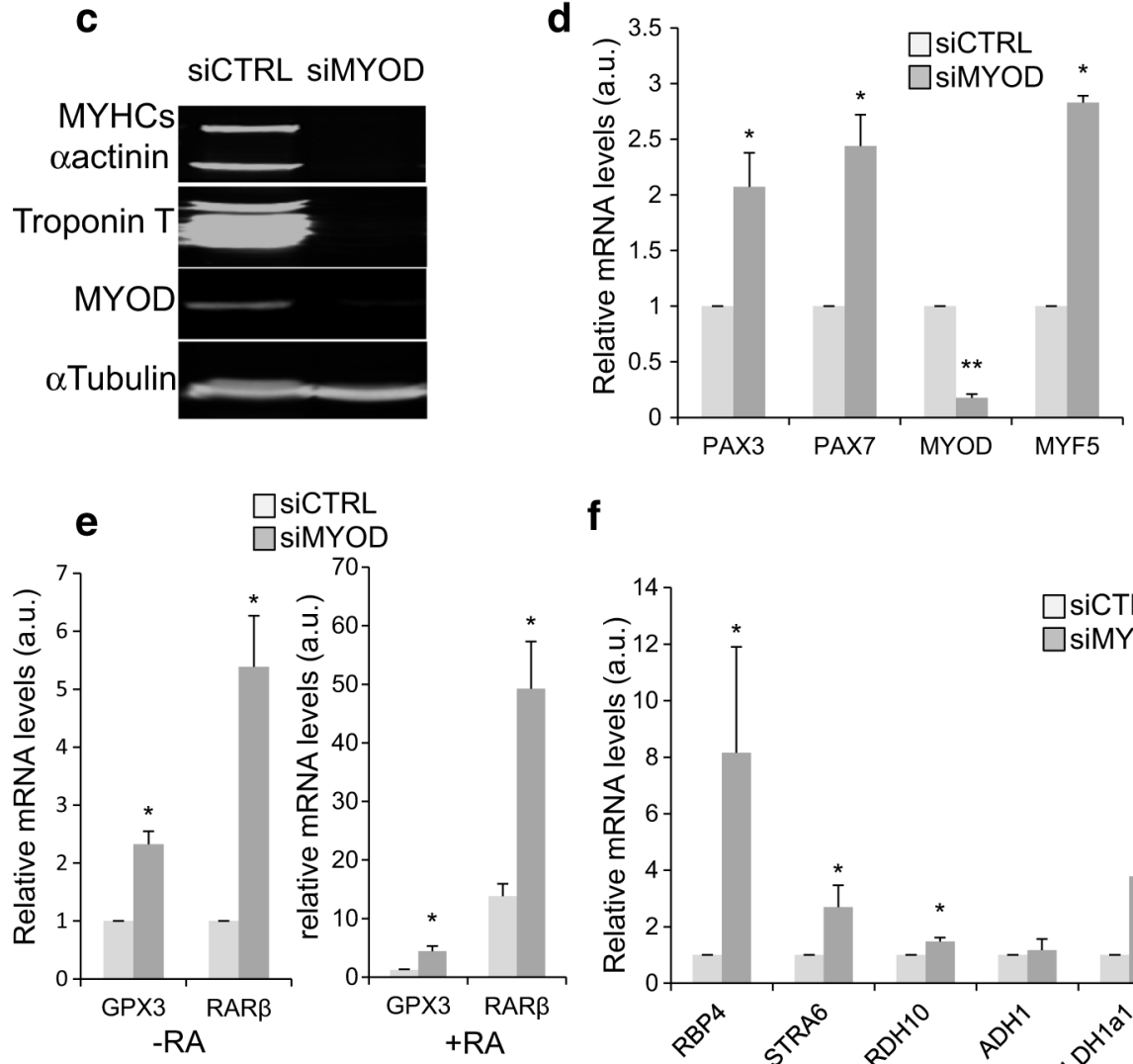

f

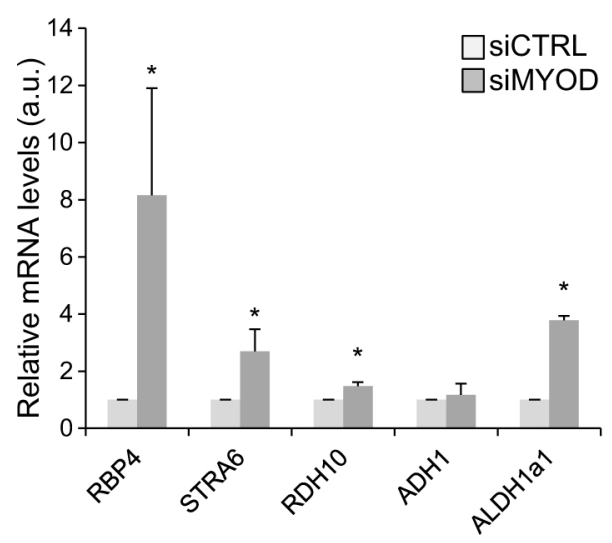


(Fig. 5c). In contrast, $10^{-6} \mathrm{M}$ RA significantly down-regulated MYOD and myogenin-positive cells after $96 \mathrm{~h}$ of RA treatment (Fig. 5c). Therefore, sustain RA treatment during satellite cell activation has no effect on their progression into the cell cycle but delayed their entry into differentiation.

\section{MYOD silencing renders human myoblast more immature and enhances RA-signalling pathway}

Freshly isolated human satellite cells are very rare. Therefore, it is difficult to obtain enough immature cells to explore the RA-signalling pathway in human. MYOD is an essential gene controlling the differentiation process in muscle precursor cells. Myoblasts inactivated for MYOD display characteristics that are more primitive than wildtype myoblasts and may represent an intermediate stage between satellite and myoblast cells [33]. To determine whether MYOD inhibition is crucial for maintaining human myoblasts at an immature stage, we knocked down MYOD using specific siRNAs (siMYOD). Immunofluorescence analysis after induction of differentiation showed loss of myogenin (red) and Troponin $\mathrm{T}$ (green) expression in silenced cells compared to controls (siCTRL) (Fig. 6a, b). siRNA-mediated inhibition of $M Y O D$ and muscle differentiation was confirmed by western blot analysis of MYOD and the differentiation markers MYHC slow (MYHCs), alpha actinin ( $\alpha$-actinin), and Troponin $\mathrm{T}$ (Fig. 6c). RT-qPCR quantification of PAX7, PAX3, $M Y O D$, and MYF5 expression in silenced cells (Fig. 6d) showed a very strong reduction of $M Y O D$ mRNA in siMYOD myoblasts, whereas MYF5 was strongly increased. This is not surprising, because MYOD and $M Y F 5$ can cross-regulate their expressions [34]. In siMYOD myoblasts, the determination genes $P A X 7$ and $P A X 3$ were significantly up-regulated. As expected, these results show that inactivation of $M Y O D$ renders human myoblasts more immature. To determine the status of RA signalling in siMYOD immature human myoblasts, we first quantified the level of two RA-target genes, $R A R \beta$ and $G P X 3$, after incubation or not with $10^{-7} \mathrm{M}$ RA for 2 days (Fig. 6e). In the absence of RA, siMYOD myoblasts showed a significant increase in $R A R \beta$ and GPX3 expression compared with siCTRL cells. Their up-regulation in siMYOD myoblasts was further promoted upon incubation with RA (Fig. 6e). Then, we analysed expression of genes encoding factors involved in RA biosynthesis (RBP4, STRA6, RDH10, ADH1, and $A L D H 1 a 1$ ) by RT-qPCR analysis (Fig. 6f). RBP4, STRA6, $R D H 10$, and $A L D H 1 a 1$, but not $A D H 1$, were significantly increased in siMYOD myoblasts. Taken together, these results show that RA-signalling pathway is more active in myoblasts in which MYOD has been silenced, thus mirroring cells at an earlier immature stage of myogenesis.

\section{Discussion}

We have examined the role of RA signalling in myogenic progenitor cells. Using ex vivo cultured mouse satellite cells and primary cultures of human myoblasts, we demonstrate that (1) RA signalling is more active in quiescent than in activated satellite cells and (2) stimulation of RA signalling impairs the differentiation process of mice satellite cells and human myoblasts. Therefore, our data reveal an important role of RA signalling in maintaining myogenic cells in an upstream immature state.

The control of the transition between quiescent and activated satellite cells is important to ensure efficient skeletal muscle regeneration. Several studies partially identified the molecules and/or signalling pathways involved in triggering cell quiescence. After muscle injury, Sprouty1 (SPRY1), an inhibitor of receptor tyrosine kinase signalling, promotes the return to quiescence of a subpopulation of satellite cells [35]. Angiopoietin and its receptor TIE-2 decrease human and mouse myoblast proliferation and differentiation and drive myoblast reversion into satellite-like cells [36]. Recently, it has been demonstrated the requirement of NOTCH signalling for the maintenance of the quiescent state and for muscle stem cell homeostasis [15, 16].

Using purified satellite cells derived from mice that express the GFP reporter gene under the control of the Pax7 locus and human myoblasts rendered immature by MYOD silencing, we show the first evidences that the RAsignalling pathway belongs to the signalling network involved in the control of muscle progenitor immaturity. Specifically, overexpression of genes involved in RA-signalling and RA-target genes in immature/quiescent myogenic precursors suggests that the RA-signalling pathway is activated in such cells. This could indicate that satellite cells produce local endogenous retinoids. Recently, Di Rocco et al. found an increase in retinoid signalling few days after skeletal muscle injury in mice [37]. In the future, it will be important to monitor in vivo changes in retinoid signalling precisely in quiescent and activated satellite cells.

We show that sustain activation of RA-signalling pathway by incubation of activated mice satellite cells and human myoblasts with RA impairs reversibly their differentiation. We also reported that inactivation of $R A R S$ enhance myoblast differentiation suggesting that unliganded RARs are negative regulators of myogenesis. Treatment with the pharmacological compound BMS93 (an inverse antagonist of RARs) enhanced myoblast fusion 
and consequently myotube area. Using specific knockdown of $R A R s$ by an siRNA approach, we demonstrated that inactivation of $R A R \beta$ and $R A R \gamma$ but not $R A R \alpha$ improves myoblast differentiation. It is interesting to note that $\operatorname{Rar} \beta$ and Rar $\gamma$ but not Rar $\alpha$ are overexpressed in mice quiescent satellite cells, consistent with the transcriptomic data of Pallafacchina and collaborators (supplementary Tables 2 and 3 in [38]). Altogether, these data suggest that $\operatorname{RAR} \beta$ and/or $\operatorname{RAR} \gamma$ have a distinct biological function from RAR $\alpha$ in muscle cells. In addition to its negative effect on human myoblast differentiation, RA inhibited myogenic differentiation of primary cultures of mice embryonic somites, limb buds, and neonatal limbs [41]. Inhibition of myogenesis by RA was also observed in chicken mesenchymal cells and in cell cultures prepared from limb buds [42, 43]. Interestingly, it was recently proposed that the timing of limb myoblast differentiation in chicken embryos is partly controlled by an RA gradient in which high RA levels in the proximal limb bud would maintain muscle progenitor cell immature [24, 44]. However, findings are apparently contradictory, as the development of the myogenic lineage can be inhibited by the absence but also by an excess of RA [20, 22-24, 41, 45].

RA inhibition of human muscle differentiation is probably the result of RA-mediated inhibition of the expression of genes of the MYOD family (MYOD, MYF5 and MYOGENIN). Myoblasts expressed MYOD and MYF5, but with distinct and contrasting expression patterns during differentiation: MYOD, together with myogenin, is expressed in differentiating myofibres and MYF5 in quiescent undifferentiated myoblasts [46]. It has been reported that, in cultured mouse myoblasts, a subset of PAX7/MYODpositive cells down-regulate MYOD, stop differentiating and become quiescent and immature [6, 47]. In addition, mice and human myoblats inactivated for $M Y O D$ do not differentiate and display some characteristics of satellite cells ([33]; our results). Therefore, MYOD can control the myogenic capacity of muscle cells and their degree of immaturity. However, distinguishing the specific functions of MYOD and MYF5 is complicated by their abilities to cross-regulate their expressions [34]. RA acts in a biphasic manner on the expression of $M Y O D$ genes, with a rapid and early inhibition of $M Y O D$ and MYF5 expression and a much later down-regulation of MYOGENIN expression that parallels the inhibition of genes related to myogenic differentiation. The rapid inhibition of MYOD gene expression by RA will certainly alter the development of the muscle differentiation program. We tried to rescue the negative effect of RA on muscle differentiation by ectopically re-expressing MYOD in RA-treated cells, but we did not succeed to over-express high levels of exogeneous MYOD in human myoblast (data not shown). The negative effect of RA on Myod (and myogenin) expression and on muscle differentiation was observed also after RA treatment of primary cultures from neonatal mouse muscles [41]. RA also blocks myoblast transdifferentiation into osteoblasts and adipocytes (Fig. s2; Supplementary materials). This may be surprising, because the muscle, adipocyte, and osteoblast differentiation programmes are supposed to be mutually exclusive [39]. However, when MyoD expression is silenced in mouse $\mathrm{C} 2$ myoblasts, myogenic differentiation but also osteoblast transdifferentiation are inhibited [40].

Taken together, these data suggest that RA, by inhibiting myogenic cell differentiation but not determination, maintains human muscle progenitor cells in an immature stage.

Previous studies have reported that the change in myogenic immaturity state can have repercussions on the efficacy of cell therapy approaches. Quiescent immature satellite cells grafted in muscles of nude $m d x$ mice contribute to the repair of the fibres and the compartment of muscle satellite cells. However, ex vivo expansion of these cells in culture prior to transplantation reduces their regenerative capacity [13]. There is an interesting correlation between the redox status of satellite cells and myoblasts and their effectiveness in regenerating skeletal muscle. Satellite cells are more resistant than myoblasts to oxidative stress induced by peroxide hydrogen treatment. Among the factors that confer resistance to toxic molecules, antioxidant and detoxifying enzymes are highly expressed in satellite cells and at lower levels in myoblasts [38]. Recently, we reported that RA treatment enhances human myoblast survival ex vivo after transplantation in scid mice and increases GPX3 expression [28]. Here, we showed that $G p x 3$ is overexpressed in mice satellite cells and in siMYOD immature human myoblasts (Figs. 5b, 6e; see also transcriptomic data in [38] and additional table for transcriptomic analysis in [48]). As most components of the RA-signalling pathway are expressed at the highest level in quiescent satellite cells, RA might be important for regulating cell survival to oxidative stress.

The control of the ex vivo status of human myoblasts on their in vivo regenerative capacity following transplantation is emerging as an important facet of stem cell biology. Previous studies have reported a negative correlation between the level of myoblast differentiation and transplantation efficiency. After transplantation, most myoblasts have already differentiated by day 5 , thus limiting the transplantation efficacy. However, when human myoblasts are transplanted in serum-containing medium, they show increased proliferation and dispersion while maintaining their ability to differentiate [49]. Similarly, activation of the NOTCH pathway, co-culture with pro-inflammatory macrophages $[50,51]$ and modifications of the culture 
substrate rigidity to mimic the muscle tissue elasticity [52], prevents differentiation and enhances transplantation efficacy. In addition, since apoptotic cells were detected during terminal differentiation of myoblasts [53], slowing down the process of terminal differentiation may protect them from apoptosis. Interestingly, Myod null satellite cells display a delayed differentiation and survive better as apoptosis is suppressed [33]. Altogether, these results suggest that changes in myoblast culture conditions by the addition of factors that reversibly inhibit differentiation and improve immaturity and cell viability, such as RA, might increase the efficiency of host skeletal muscle colonization by transplanted myoblasts.

In conclusion, we provide the first evidences that the RA-signalling pathway could be part of a network of molecules that restrict myoblast commitment, maintaining myogenic cells in an upstream immature state.

Acknowledgements This work was supported by CNRS, INSERM, and by Montpellier University Grants. M. El Haddad was supported by a Ph.D. studentship from the Centre Hospitalier Regional Universitaire of Montpellier and the University of Montpellier. We thank Dr. Pierre Germain (Centre de Biochimie Structurale, CNRS UMR5048/INSERM U1054, Montpellier, France) for his helpful discussions.

\section{Compliance with ethical standards}

Conflict of interest The authors have declared no conflict of interest

\section{References}

1. Dumont NA, Wang YX, Rudnicki MA (2015) Intrinsic and extrinsic mechanisms regulating satellite cell function. Development 142:1572-1581

2. Sambasivan R, Yao R, Kissenpfennig A, Van Wittenberghe L, Paldi A, Gayraud-Morel B, Guenou H, Malissen B, Tajbakhsh S, Galy A (2011) Pax7-expressing satellite cells are indispensable for adult skeletal muscle regeneration. Development 138:3647-3656

3. Lepper C, Partridge TA, Fan CM (2011) An absolute requirement for Pax7-positive satellite cells in acute injury-induced skeletal muscle regeneration. Development 138:3639-3646

4. Chang NC, Rudnicki MA (2014) Satellite cells: the architects of skeletal muscle. Curr Top Dev Biol 107:161-181

5. Chang NC, Chevalier FP, Rudnicki MA (2016) Satellite cells in muscular dystrophy-lost in polarity. Trends Mol Med 22:479-496

6. Zammit PS, Golding JP, Nagata Y, Hudon V, Partridge TA, Beauchamp JR (2004) Muscle satellite cells adopt divergent fates: a mechanism for self-renewal? J Cell Biol 166:347-357

7. Wang YX, Dumont NA, Rudnicki MA (2014) Muscle stem cells at a glance. J Cell Sci

8. Partridge TA, Morgan JE, Coulton GR, Hoffman EP, Kunkel LM (1989) Conversion of $\mathrm{mdx}$ myofibres from dystrophin-negative to -positive by injection of normal myoblasts. Nature 337:176-179

9. Gussoni E, Blau HM, Kunkel LM (1997) The fate of individual myoblasts after transplantation into muscles of DMD patients. Nat Med 3:970-977
10. Mendell JR, Kissel JT, Amato AA, King W, Signore L, Prior TW, Sahenk Z, Benson S, McAndrew PE, Rice R et al (1995) Myoblast transfer in the treatment of Duchenne's muscular dystrophy. N Engl J Med 333:832-838

11. Tremblay JP, Malouin F, Roy R, Huard J, Bouchard JP, Satoh A, Richards CL (1993) Results of a triple blind clinical study of myoblast transplantations without immunosuppressive treatment in young boys with Duchenne muscular dystrophy. Cell Transplant 2:99-112

12. Beauchamp JR, Morgan JE, Pagel CN, Partridge TA (1999) Dynamics of myoblast transplantation reveal a discrete minority of precursors with stem cell-like properties as the myogenic source. J Cell Biol 144:1113-1122

13. Montarras D, Morgan J, Collins C, Relaix F, Zaffran S, Cumano A, Partridge T, Buckingham M (2005) Direct isolation of satellite cells for skeletal muscle regeneration. Science 309:2064-2067

14. Ikemoto M, Fukada S, Uezumi A, Masuda S, Miyoshi $\mathrm{H}$, Yamamoto H, Wada MR, Masubuchi N, Miyagoe-Suzuki Y, Takeda S (2007) Autologous transplantation of SM/C-2.6(+) satellite cells transduced with micro-dystrophin CS1 cDNA by lentiviral vector into $\mathrm{mdx}$ mice. Mol Ther 15:2178-2185

15. Bjornson CR, Cheung TH, Liu L, Tripathi PV, Steeper KM, Rando TA (2012) Notch signaling is necessary to maintain quiescence in adult muscle stem cells. Stem Cells 30:232-242

16. Mourikis P, Sambasivan R, Castel D, Rocheteau P, Bizzarro V, Tajbakhsh $S$ (2012) A critical requirement for notch signaling in maintenance of the quiescent skeletal muscle stem cell state. Stem Cells 30:243-252

17. Huang P, Chandra V, Rastinejad F (2014) Retinoic acid actions through mammalian nuclear receptors. Chem Rev 114:233-254

18. Rochette-Egly C, Germain P (2009) Dynamic and combinatorial control of gene expression by nuclear retinoic acid receptors (RARs). Nucl Recept Signal 7:e005

19. Hauksdottir H, Farboud B, Privalsky ML (2003) Retinoic acid receptors beta and gamma do not repress, but instead activate target gene transcription in both the absence and presence of hormone ligand. Mol Endocrinol 17:373-385

20. Albagli-Curiel O, Carnac G, Vandromme M, Vincent S, Crepieux P, Bonnieu A (1993) Serum-induced inhibition of myogenesis is differentially relieved by retinoic acid and triiodothyronine in $\mathrm{C} 2$ murine muscle cells. Differentiation 52:201-210

21. Amengual J, Ribot J, Bonet ML, Palou A (2008) Retinoic acid treatment increases lipid oxidation capacity in skeletal muscle of mice. Obesity (Silver Spring) 16:585-591

22. Maden M, Graham A, Zile M, Gale E (2000) Abnormalities of somite development in the absence of retinoic acid. Int $\mathbf{J}$ Dev Biol 44:151-159

23. Hamade A, Deries M, Begemann G, Bally-Cuif L, Genet C, Sabatier F, Bonnieu A, Cousin X (2006) Retinoic acid activates myogenesis in vivo through Fgf8 signalling. Dev Biol 289:127-140

24. Reijntjes S, Francis-West P, Mankoo BS (2010) Retinoic acid is both necessary for and inhibits myogenic commitment and differentiation in the chick limb. Int J Dev Biol 54:125-134

25. Jean E, Laoudj-Chenivesse D, Notarnicola C, Rouger K, Serratrice N, Bonnieu A, Gay S, Bacou F, Duret C, Carnac G (2011) Aldehyde dehydrogenase activity promotes survival of human muscle precursor cells. J Cell Mol Med 15:119-133

26. Vauchez K, Marolleau JP, Schmid M, Khattar P, Chapel A, Catelain C, Lecourt S, Larghero J, Fiszman M, Vilquin JT (2009) Aldehyde dehydrogenase activity identifies a population of human skeletal muscle cells with high myogenic capacities. Mol Ther 17:1948-1958

27. Vella JB, Thompson SD, Bucsek MJ, Song M, Huard J (2011) Murine and human myogenic cells identified by elevated 
aldehyde dehydrogenase activity: implications for muscle regeneration and repair. PLoS One 6:e29226

28. El Haddad M, Jean E, Turki A, Hugon G, Vernus B, Bonnieu A, Passerieux E, Hamade A, Mercier J, Laoudj-Chenivesse D, Carnac G (2012) Glutathione peroxidase 3, a new retinoid target gene, is crucial for human skeletal muscle precursor cell survival. J Cell Sci 125:6147-6156

29. Sambasivan R, Gayraud-Morel B, Dumas G, Cimper C, Paisant S, Kelly RG, Tajbakhsh S (2009) Distinct regulatory cascades govern extraocular and pharyngeal arch muscle progenitor cell fates. Dev Cell 16:810-821

30. Germain P, Gaudon C, Pogenberg V, Sanglier S, Van Dorsselaer A, Royer CA, Lazar MA, Bourguet W, Gronemeyer H (2009) Differential action on coregulator interaction defines inverse retinoid agonists and neutral antagonists. Chem Biol 16:479-489

31. Samarut E, Rochette-Egly C (2012) Nuclear retinoic acid receptors: conductors of the retinoic acid symphony during development. Mol Cell Endocrinol 348:348-360

32. Kedishvili NY (2013) Enzymology of retinoic acid biosynthesis and degradation. J Lipid Res 54:1744-1760

33. Asakura A, Hirai H, Kablar B, Morita S, Ishibashi J, Piras BA, Christ AJ, Verma M, Vineretsky KA, Rudnicki MA (2007) Increased survival of muscle stem cells lacking the MyoD gene after transplantation into regenerating skeletal muscle. Proc Natl Acad Sci USA 104:16552-16557

34. Rudnicki MA, Braun T, Hinuma S, Jaenisch R (1992) Inactivation of MyoD in mice leads to up-regulation of the myogenic HLH gene Myf-5 and results in apparently normal muscle development. Cell 71:383-390

35. Shea KL, Xiang W, LaPorta VS, Licht JD, Keller C, Basson MA, Brack AS (2010) Sprouty1 regulates reversible quiescence of a self-renewing adult muscle stem cell pool during regeneration. Cell Stem Cell 6:117-129

36. Abou-Khalil R, Le Grand F, Pallafacchina G, Valable S, Authier FJ, Rudnicki MA, Gherardi RK, Germain S, Chretien F, Sotiropoulos A, Lafuste P, Montarras D, Chazaud B (2009) Autocrine and paracrine angiopoietin 1/Tie-2 signaling promotes muscle satellite cell self-renewal. Cell Stem Cell 5:298-309

37. Di Rocco A, Uchibe K, Larmour C, Berger R, Liu M, Barton ER, Iwamoto M (2015) Selective retinoic acid receptor gamma agonists promote repair of injured skeletal muscle in mouse. Am J Pathol 185:2495-2504

38. Pallafacchina G, Francois S, Regnault B, Czarny B, Dive V, Cumano A, Montarras D, Buckingham M (2010) An adult tissuespecific stem cell in its niche: A gene profiling analysis of in vivo quiescent and activated muscle satellite cells. Stem Cell Res

39. Li WC, Yu WY, Quinlan JM, Burke ZD, Tosh D (2005) The molecular basis of transdifferentiation. J Cell Mol Med 9:569-582

40. Hewitt J, Lu X, Gilbert L, Nanes MS (2008) The muscle transcription factor MyoD promotes osteoblast differentiation by stimulation of the Osterix promoter. Endocrinology 149:3698-3707
41. Xiao Y, Grieshammer U, Rosenthal N (1995) Regulation of a muscle-specific transgene by retinoic acid. J Cell Biol 129:1345-1354

42. Robson LG, Kara T, Crawley A, Tickle C (1994) Tissue and cellular patterning of the musculature in chick wings. Development 120:1265-1276

43. Langille RM, Paulsen DF, Solursh M (1989) Differential effects of physiological concentrations of retinoic acid in vitro on chondrogenesis and myogenesis in chick craniofacial mesenchyme. Differentiation 40:84-92

44. Mok GF, Cardenas R, Anderton H, Campbell KH, Sweetman D (2014) Interactions between FGF18 and retinoic acid regulate differentiation of chick embryo limb myoblasts. Dev Biol 396:214-223

45. Downie D, Antipatis C, Delday MI, Maltin CA, Sneddon AA (2005) Moderate maternal vitamin A deficiency alters myogenic regulatory protein expression and perinatal organ growth in the rat. Am J Physiol Regul Integr Comp Physiol 288:R73-R79

46. Kitzmann M, Carnac G, Vandromme M, Primig M, Lamb N, Fernandez A (1998) The muscle regulatory factors MyoD and myf-5 undergo distinct cell cycle-specific expression in muscle cells. J Cell Biol 142:1447-1459

47. Olguin HC, Olwin BB (2004) Pax-7 up-regulation inhibits myogenesis and cell cycle progression in satellite cells: a potential mechanism for self-renewal. Dev Biol 275:375-388

48. Fukada S, Uezumi A, Ikemoto M, Masuda S, Segawa M, Tanimura N, Yamamoto H, Miyagoe-Suzuki Y, Takeda S (2007) Molecular signature of quiescent satellite cells in adult skeletal muscle. Stem Cells 25:2448-2459

49. Riederer I, Negroni E, Bencze M, Wolff A, Aamiri A, Di Santo JP, Silva-Barbosa SD, Butler-Browne G, Savino W, Mouly V (2011) Slowing down differentiation of engrafted human myoblasts into immunodeficient mice correlates with increased proliferation and migration. Mol Ther 20:146-154

50. Bencze M, Negroni E, Vallese D, Yacoub-Youssef H, Chaouch S, Wolff A, Aamiri A, Di Santo JP, Chazaud B, Butler-Browne G, Savino W, Mouly V, Riederer I (2012) Proinflammatory macrophages enhance the regenerative capacity of human myoblasts by modifying their kinetics of proliferation and differentiation. Mol Ther 20:2168-2179

51. Lesault PF, Theret M, Magnan M, Cuvellier S, Niu Y, Gherardi RK, Tremblay JP, Hittinger L, Chazaud B (2012) Macrophages improve survival, proliferation and migration of engrafted myogenic precursor cells into MDX skeletal muscle. PLoS One 7:e46698

52. Gilbert PM, Havenstrite KL, Magnusson KE, Sacco A, Leonardi NA, Kraft P, Nguyen NK, Thrun S, Lutolf MP, Blau HM (2010) Substrate elasticity regulates skeletal muscle stem cell self-renewal in culture. Science 329:1078-1081

53. Shiokawa D, Kobayashi T, Tanuma S (2002) Involvement of DNase gamma in apoptosis associated with myogenic differentiation of C2C12 cells. J Biol Chem 277:31031-31037 